\title{
Occurrence and Sources of Radium in Groundwater Associated with Oil Fields in the Southern San Joaquin Valley, California
}

Peter B. McMahon, ${ }^{*} \dagger \odot$ Avner Vengosh, ${ }^{\ddagger}$ Tracy A. Davis, ${ }^{\S}$ Matthew K. Landon, ${ }^{\S}$ Rebecca L. Tyne, Michael T. Wright, ${ }^{\S}$ Justin T. Kulongoski, ${ }^{\S}$ Andrew G. Hunt, ${ }^{\dagger}$ Peter H. Barry, ${ }^{\|, \perp}$ Andrew J. Kondash, ${ }^{\dagger}$ Zhen Wang, and Chris J. Ballentine

${ }^{\dagger}$ U.S. Geological Survey, Lakewood, Colorado 80225, United States

${ }^{\ddagger}$ Division of Earth and Ocean Sciences, Nicholas School of the Environment, Duke University, Durham, North Carolina 27708, United States

${ }^{\S}$ U.S. Geological Survey, San Diego, California 92101, United States

"Department of Earth Sciences, University of Oxford, Oxford OX1 3AN, U.K.

\section{Supporting Information}

ABSTRACT: Geochemical data from 40 water wells were used to examine the occurrence and sources of radium $(\mathrm{Ra})$ in groundwater associated with three oil fields in California (Fruitvale, Lost Hills, South Belridge). ${ }^{226} \mathrm{Ra}+{ }^{228} \mathrm{Ra}$ activities (range $=0.010-0.51 \mathrm{~Bq} / \mathrm{L}$ ) exceeded the $0.185 \mathrm{~Bq} / \mathrm{L}$ drinking-water standard in $18 \%$ of the wells (not drinkingwater wells). Radium activities were correlated with TDS concentrations $(p<0.001, \rho=0.90$, range $=145-15,900 \mathrm{mg} / \mathrm{L}), \mathrm{Mn}+\mathrm{Fe}$ concentrations $(p<0.001, \rho=0.82$, range $=<0.005-18.5 \mathrm{mg} / \mathrm{L})$, and $\mathrm{pH}(p<0.001, \rho=-0.67$, range $=6.2-9.2)$, indicating Ra in groundwater was influenced by salinity, redox, and $\mathrm{pH}$. Ra-rich groundwater was mixed with up to $45 \%$ oil-field water at some locations, primarily infiltrating through unlined disposal ponds, based on $\mathrm{Cl}$, Li, noble-gas, and other data. Yet ${ }^{228} \mathrm{Ra} /{ }^{226} \mathrm{Ra}$ ratios in pond-impacted groundwater (median $=3.1$ ) differed from those in oil-field water (median $=$ 0.51). PHREEQC mixing calculations and spatial geochemical variations suggest that the $\mathrm{Ra}$ in the oil-field water was removed by coprecipitation with secondary barite and adsorption on $\mathrm{Mn}-\mathrm{Fe}$ precipitates in the near-pond environment. The saline, organic-rich oil-field water subsequently mobilized $\mathrm{Ra}$ from downgradient aquifer sediments via $\mathrm{Ra}$-desorption and $\mathrm{Mn} / \mathrm{Fe}$ reduction processes. This study demonstrates that infiltration of oil-field water may leach Ra into groundwater by changing salinity and redox conditions in the subsurface rather than by mixing with a high-Ra source.

\section{INTRODUCTION}

Consumption of water containing elevated radium ( $\mathrm{Ra}$ ) activities has been associated with various adverse humanhealth effects, including some forms of cancer. ${ }^{1-3}$ The U.S. Environmental Protection Agency established a maximum contaminant level (MCL) for ${ }^{226} \mathrm{Ra}+{ }^{228} \mathrm{Ra}$ in drinking water of $0.185 \mathrm{~Bq} / \mathrm{L}(5 \mathrm{pCi} / \mathrm{L}) .{ }^{4}$ Previous studies have shown that water in some hydrocarbon reservoirs is enriched in Ra nuclides, which could be problematic if that water mixes with nearby groundwater. ${ }^{226} \mathrm{Ra}+{ }^{228} \mathrm{Ra}$ activities up to 666 and $64 \mathrm{~Bq} / \mathrm{L}$ were reported in produced water from unconventional hydrocarbon reservoirs in the Marcellus Shale and Bakken Formation, respectively. ${ }^{5,6}$ Produced water from oil reservoirs in the southern San Joaquin Valley (SJV), California, has reported ${ }^{226} \mathrm{Ra}+{ }^{228} \mathrm{Ra}$ activities up to $\sim 12 \mathrm{~Bq} / \mathrm{L}$. ${ }^{7,8}$ Differences in $\mathrm{Ra}$ activities between water from the SJV and other reservoirs reflect, in part, differences in salinity between the reservoirs. At elevated salinities, exchangeable Ra on clay minerals can be mobilized due to exchange with other dissolved ions. ${ }^{9-11}$ While concentrations of total dissolved solids (TDS) in water from SJV oil reservoirs are typically $<40,000 \mathrm{mg} / \mathrm{L},{ }^{8} \mathrm{TDS}$ in water from the Bakken and Marcellus commonly exceed 100,000 mg/L. 5,6

The focus of this study is shallow groundwater associated with the Fruitvale (FV), Lost Hills (LH), and South Belridge (SB) oil fields in the SJV (Figure 1), ${ }^{12}$ where oil production has occurred for $\sim 100$ years. ${ }^{8}$ Disposal of oil-field water in unlined ponds has occurred in parts of the study area since the 1950s and is a direct pathway for oil-field water to enter the near-surface environment. ${ }^{13}$ Several studies have reported the presence of Ra from oil-field water in near-surface environments, typically in aquatic sediment or soil associated with releases of Ra-rich produced water. ${ }^{6,14-16}$ Those studies found most of the Ra was retained on solid phases relatively close to the release site due to $\mathrm{Ra}$ immobilization by processes like coprecipitation with barite $\left(\mathrm{BaSO}_{4}\right)$ and adsorption on solid phases. ${ }^{6,14,15}$ In groundwater

Received: April 19, 2019

Revised: July 24, 2019

Accepted: July 26, 2019

Published: August 7, 2019 

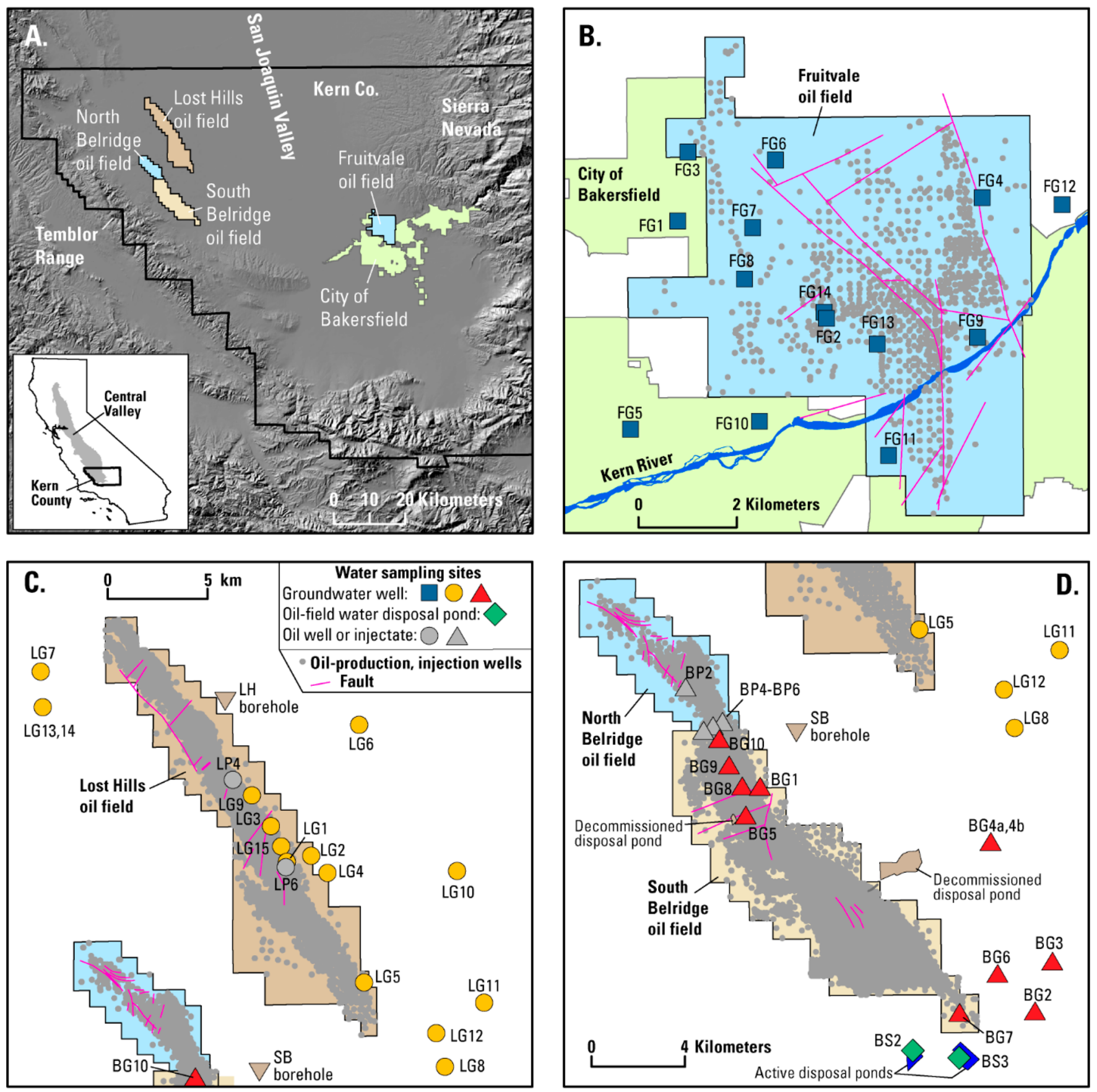

Figure 1. (A) Location of the study-area oil fields, and locations of sampling sites in the (B) Fruitvale, (C) Lost Hills, and (D) South Belridge oil fields. Oil-well data from ref 12 . Only selected active and decommissioned disposal ponds are shown.

systems, subsequent brine migration and mixing with fresh groundwater could mobilize $\mathrm{Ra}$ associated with the aquifer sediments, given the direct influence of salinity on $\mathrm{Ra}$ sorption. ${ }^{9,17}$ Mobilization of Ra from aquifer sediments could also occur if brine incursion into aquifers shifts $\mathrm{pH}$ to acidic conditions or induces redox to more reducing conditions, which would enhance Ra release to groundwater. ${ }^{11,18,19}$ As far as we are aware, only one study has examined $\mathrm{Ra}$ in groundwater near hydrocarbon production activities to evaluate such processes. ${ }^{14}$ This study examines the occurrence and sources of $\mathrm{Ra}$ in groundwater associated with the FV, LH, and SB oil fields. In particular, this study aims to distinguish the impact of oil-field water disposed of in unlined ponds relative to subsurface mixing processes between oil-field water and regional groundwater.

\section{MATERIALS AND METHODS}

The study area is in the southern SJV (Figure 1), part of the Central Valley of California, a 700-km-long basin containing > $7500 \mathrm{~m}$ of Mesozoic through Cenozoic-aged sediments. ${ }^{20}$ From 2014 to 2017, water samples were collected from 40 water wells located in, or near (within $5 \mathrm{~km}$ ), the three oil fields (Figure 1, Table S1). A detailed description of the study area is provided in Section S1 and briefly summarized here. In the FV oil field, located on the east side of the SJV, sampled wells are screened in semiconsolidated gravel, sand, silt, and clay in late Miocene to 

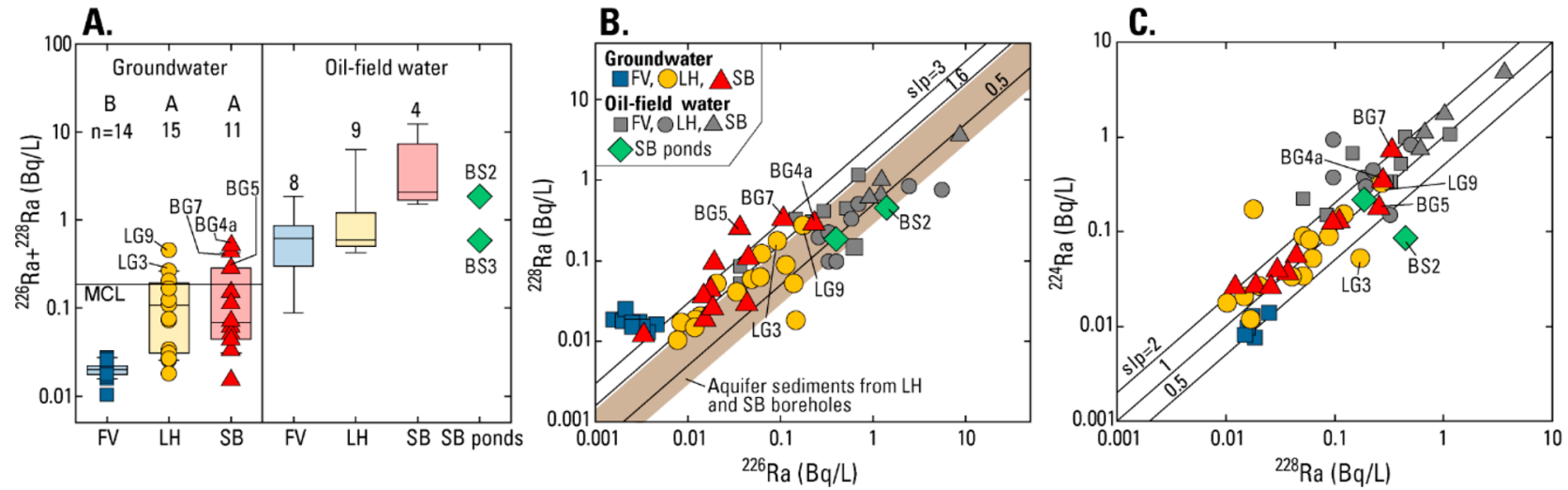

Figure 2. (A) ${ }^{226} \mathrm{Ra}+{ }^{228} \mathrm{Ra}$ activities, (B) ${ }^{228} \mathrm{Ra}$ activities in relation to ${ }^{226} \mathrm{Ra}$ activities, and (C) ${ }^{224} \mathrm{Ra}$ activities in relation to ${ }^{228} \mathrm{Ra}$ activities, in groundwater and oil-field water. Data for oil-field water from refs 8 and 31. In (A), boxes represent 25th, 50th, and 75th percentile values, whiskers represent 10th and 90th percentile values; oil fields with different letters (A or B) at the top of the panel have significantly different activities based on Tukey multiple-comparison tests and $\alpha=0.05$; n, number of samples. In (B), data for aquifer sediments in Table S5 and ref 37 are present. FV, Fruitvale oil field; LH, Lost Hills oil field; SB, South Belridge oil field; slp, slope.

Pleistocene fluvial deposits in the Kern River Formation (Figure S1). ${ }^{21}$ Those sediments were largely derived from granitic rocks in the Sierra Nevada to the east. ${ }^{22}$ Groundwater flow directions are generally to the west, southwest. ${ }^{21}$ The median depth to the bottom of perforations in the sampled water wells is $209 \mathrm{~m}$, whereas the median depth to the top of perforations in FV oil wells is $1088 \mathrm{~m} .^{23}$ Sediments in the Kern River Formation and marine sediments in the underlying Etchegoin Formation are present between the deepest water wells and shallowest oil wells (completed in basal portions of the Etchegoin Formation) (Figure S1). ${ }^{24}$ The Macoma Claystone, within the basal portion of the Etchegoin Formation, generally serves as a hydraulic barrier between the oil and water-bearing zones. ${ }^{24}$

In the SB and LH oil fields, located on the west side of the SJV, sampled wells are screened in unconsolidated to semiconsolidated sand, silt, and clay in Holocene/Pleistocene alluvium and fluvial, deltaic, to lacustrine deposits in the Tulare Formation (Pleistocene). ${ }^{25}$ Those sediments were largely derived from marine rocks in the Temblor Range to the west. $^{25}$ Groundwater flow directions are generally to the northeast. ${ }^{26}$ The aquifers are generally unconfined to semiconfined, except for water-bearing units in the Tulare Formation, which are confined by the Corcoran Clay. ${ }^{26}$ Median depths to the bottom of perforations in the sampled water wells are $199 \mathrm{~m} \mathrm{(LH)}$ and $153 \mathrm{~m}(\mathrm{SB})$. Median depths to the top of perforations in oil wells are $414 \mathrm{~m}(\mathrm{LH})$ and $326 \mathrm{~m} \mathrm{(SB)} .^{23}$ Within the LH and SB oil fields, the deepest water wells and shallowest oil wells are both completed in the Tulare Formation (Figure S1), although the Tulare oil wells in the vicinity of the sampled Tulare water wells are deeper than the water wells. In parts of LH and SB, the Amnicola, Tulare, and Corcoran Clays (deepest to shallowest) in the Tulare Formation could serve as confining layers between the oil wells and water wells. ${ }^{25,26}$

Generally, samples were collected from the wells after three casing-volumes of water were purged from the wells and readings of $\mathrm{pH}$, specific conductance, dissolved oxygen $\left(\mathrm{O}_{2}\right)$, and water temperature stabilized. Samples were also collected from two oil-field water disposal ponds (SB field) and an oil-field injectate flow manifold ( $\mathrm{LH}$ field) integrating produced waters from many oil wells for injection for enhanced oil recovery (EOR) (Figure 1). Previously published data for other oil-field water in the study areas were also used in the analysis. ${ }^{8}$ Samples were analyzed for Ra-isotope activities $\left({ }^{224} \mathrm{Ra},{ }^{226} \mathrm{Ra},{ }^{228} \mathrm{Ra}\right)$; major ions, nutrients, and trace elements; dissolved organic carbon (DOC) and volatile organic compounds (VOCs); isotopic compositions of water $\left(\delta^{2} \mathrm{H}-\mathrm{H}_{2} \mathrm{O}, \delta^{18} \mathrm{O}-\mathrm{H}_{2} \mathrm{O}\right)$, dissolved inorganic carbon $\left(\delta^{13} \mathrm{C}-\mathrm{DIC}\right)$ and $\mathrm{CH}_{4}\left(\delta^{2} \mathrm{H}-\mathrm{CH}_{4}\right.$, $\left.\delta^{13} \mathrm{C}-\mathrm{CH}_{4}\right)$; noble gas abundances $\left({ }^{4} \mathrm{He}, \mathrm{Ne}, \mathrm{Ar}, \mathrm{Kr}\right)$ and isotopes $\left({ }^{40} \mathrm{Ar} /{ }^{36} \mathrm{Ar},{ }^{86} \mathrm{Kr} /{ }^{84} \mathrm{Kr}\right) ;{ }^{3} \mathrm{H}$ and ${ }^{14} \mathrm{C}$ in DIC $\left({ }^{14} \mathrm{C}\right.$-DIC); and concentrations of $\mathrm{CH}_{4}$ through pentane $\left(\mathrm{C}_{1}-\mathrm{C}_{5}\right)$ (Tables S2, S3, and S4).

Sediment cuttings collected from two boreholes drilled by the U.S. Geological Survey near the LH and SB oil fields in 2018 were analyzed for their ${ }^{226} \mathrm{Ra}$ and ${ }^{228} \mathrm{Ra}$ activities using gamma spectrometry methods described in Section S2 (Figure 1).

Mann-Whitney and Tukey multiple comparison tests, as implemented in the software OriginPro $2018,{ }^{27}$ were used on ranked data to test for significant differences in $\mathrm{Ra}$ concentrations between study areas and other variables. Spearman correlation analysis considered relations between concentrations of $\mathrm{Ra}$ and other variables. For the statistical tests, concentrations below reporting levels were set to zero. An $\alpha$ value of 0.05 was used for each test.

\section{RESULTS AND DISCUSSION}

Radium Nuclide Occurrence in Groundwater. ${ }^{226} \mathrm{Ra}$ $+{ }^{228} \mathrm{Ra}$ activities in groundwater in the study areas range from 0.010 to $0.51 \mathrm{~Bq} / \mathrm{L}$, with $18 \%$ of the wells having ${ }^{226} \mathrm{Ra}+{ }^{228} \mathrm{Ra}$ activities greater than the MCL of $0.185 \mathrm{~Bq} / \mathrm{L}$ (Table S4). ${ }^{28-30}$ All the Ra MCL exceedances are from nondrinking-water wells in LH (LG2, LG3, LG6, LG9) and SB (BG4a, BG5, BG7). ${ }^{226} \mathrm{Ra}$ $+{ }^{228} \mathrm{Ra}$ activities in $\mathrm{LH}$ and $\mathrm{SB}$ groundwater are significantly higher $(p<0.001)$ than the activities in FV groundwater; however, ${ }^{226} \mathrm{Ra}+{ }^{228} \mathrm{Ra}$ activities in $\mathrm{LH}$ and $\mathrm{SB}$ groundwater are not significantly different $(p=0.99)$ from each other [median ${ }^{226} \mathrm{Ra}+{ }^{228} \mathrm{Ra}$ activities $(\mathrm{Bq} / \mathrm{L}) ; \mathrm{FV}=0.020, \mathrm{LH}=0.11, \mathrm{SB}=$ 0.073] (Figure 2A). In each oil field, ${ }^{226} \mathrm{Ra}+{ }^{228} \mathrm{Ra}$ activities in groundwater are significantly lower $(p<0.001)$ than the activities in the associated oil-field water (Figure 2A). ${ }^{31}{ }^{224} \mathrm{Ra}$ composes a large fraction of the total Ra inventory $\left({ }^{224} \mathrm{Ra}+{ }^{226} \mathrm{Ra}\right.$ $+{ }^{228} \mathrm{Ra}$ ) in groundwater from the $\mathrm{LH}$ and SB oil fields (median ${ }^{224} \mathrm{Ra}$ fraction; $\left.\mathrm{FV}=0, \mathrm{LH}=0.37, \mathrm{SB}=0.44\right)$.

Radium-isotope activity ratios can provide insight on $\mathrm{Ra}$ sources and processes affecting $\mathrm{Ra}$ in groundwater. ${ }^{18,32,33}{ }^{226} \mathrm{Ra}$ (half-life $=1600$ years) is part of the ${ }^{238} \mathrm{U}$ decay series and is the direct product of ${ }^{230} \mathrm{Th}$ decay. ${ }^{34}{ }^{224} \mathrm{Ra}$ and ${ }^{228} \mathrm{Ra}$ (half-lives = 

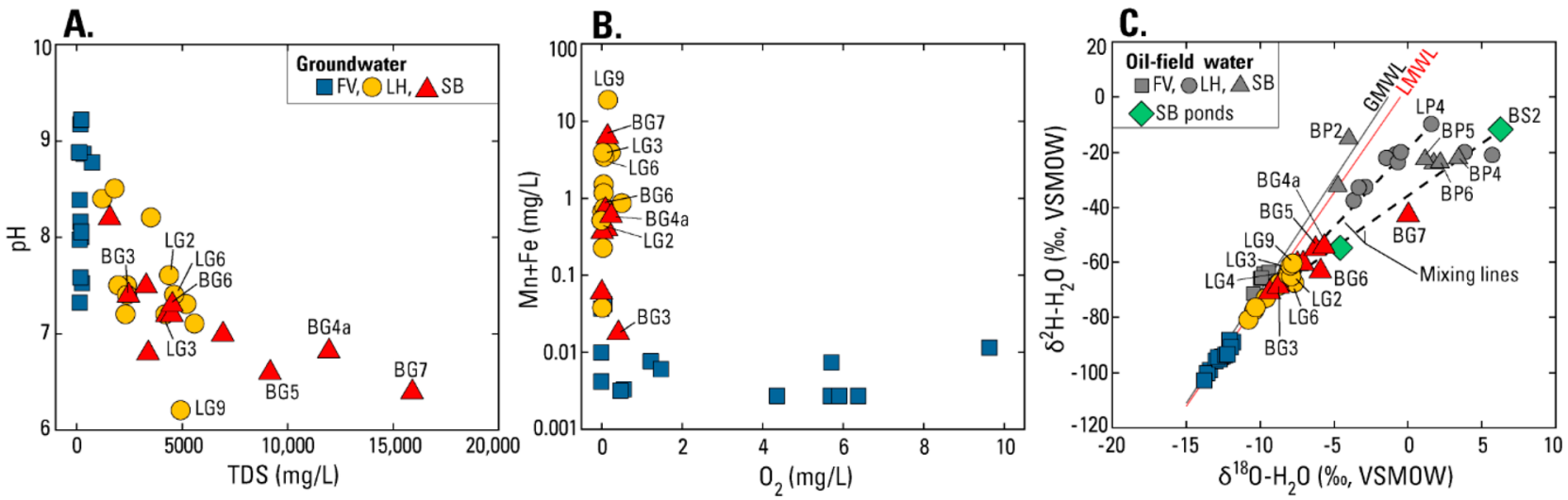

Figure 3. (A) $\mathrm{pH}$ in relation to total dissolved solids concentrations and (B) manganese + iron concentrations in relation to dissolved oxygen concentrations, in groundwater; and $(C) \delta^{2} \mathrm{H}-\mathrm{H}_{2} \mathrm{O}$ in relation to $\delta^{18} \mathrm{O}-\mathrm{H}_{2} \mathrm{O}$ in groundwater and oil-field water. Data for oil-field water from refs 8 and 31. In (C), GMWL, global meteoric water line; ${ }^{50}$ LMWL, local meteoric water line. ${ }^{51}$

3.63 days and 5.75 years, respectively), are part of the ${ }^{232} \mathrm{Th}$ decay series and are the direct products of ${ }^{228} \mathrm{Th}$ and ${ }^{232} \mathrm{Th}$ decay, respectively. ${ }^{34}{ }^{228} \mathrm{Ra} /{ }^{226} \mathrm{Ra}$ activity ratios in groundwater are generally considered to reflect the ${ }^{228} \mathrm{Ra} /{ }^{226} \mathrm{Ra}$ activity ratios in solid phases with which the groundwater is in contact. ${ }^{9,18}$ ${ }^{224} \mathrm{Ra} /{ }^{228} \mathrm{Ra}$ ratios in groundwater could be expected to be near a value of 1 , assuming secular equilibrium between ${ }^{224} \mathrm{Ra}$ and ${ }^{228} \mathrm{Ra}$ in aquifer sediments. ${ }^{18,33,35}$ Various processes could alter these ratios in groundwater. Alpha recoil, for example, releases ${ }^{224} \mathrm{Ra}$ and ${ }^{228} \mathrm{Ra}$ from sediment faster than ${ }^{226} \mathrm{Ra}$ because of the shorter half-lives of ${ }^{224} \mathrm{Ra}$ and ${ }^{228} \mathrm{Ra}$ relative to ${ }^{226} \mathrm{Ra} \cdot{ }^{33,35,36}$ As a result, subsurface flow systems undergoing relatively recent water-rock interactions could contain water with elevated ${ }^{228} \mathrm{Ra} /{ }^{226} \mathrm{Ra}$ (above the ratio in the host rocks) and ${ }^{224} \mathrm{Ra} /{ }^{228} \mathrm{Ra}$ (above the ratio of 1 ). ${ }^{18,33,35}$ Yet, over longer residence times, the ${ }^{228} \mathrm{Ra} /{ }^{226} \mathrm{Ra}$ of groundwater typically mimics the ${ }^{228} \mathrm{Ra} /{ }^{226} \mathrm{Ra}$ ratio of the host aquifer rocks.

${ }^{228} \mathrm{Ra} /{ }^{226} \mathrm{Ra}$ activity ratios in the samples span a wide range ( 0.12 to 12 ), but most samples have ratios between about 0.5 and 3 (median ${ }^{228} \mathrm{Ra} /{ }^{226} \mathrm{Ra}$ ratios; $\mathrm{FV}=6.0, \mathrm{LH}=1.3 ; \mathrm{SB}=2.4$ ) (Figure $2 \mathrm{~B}$ ). The ${ }^{228} \mathrm{Ra} /{ }^{226} \mathrm{Ra}$ ratios in FV samples are higher than those in $\mathrm{LH}$ and $\mathrm{SB}$, but the ratios in FV have relatively high analytical uncertainty due to the low $\mathrm{Ra}$ activities in those samples (Table S4). Given the low Ra activities in FV samples relative to the MCL, the remaining discussion of activity ratios focuses on the $\mathrm{LH}$ and SB samples. The median ${ }^{228} \mathrm{Ra} /{ }^{226} \mathrm{Ra}$ ratio in $\mathrm{LH}$ groundwater (1.3) is close to a previously proposed average ${ }^{228} \mathrm{Ra} /{ }^{226} \mathrm{Ra}$ ratio for sandstones of $1.6^{18}$ and is within the range of ratios measured in aquifer sediments ( 0.26 to $1.39, n$ $=10$ ) collected from the LH and SB boreholes (Figures 1 and 2B). ${ }^{37}$ The median ${ }^{228} \mathrm{Ra} /{ }^{226} \mathrm{Ra}$ ratio in SB groundwater $(2.4)$ is higher than that in LH groundwater, but the high median ratio is largely due to four samples with conspicuously high ${ }^{228} \mathrm{Ra} /{ }^{226} \mathrm{Ra}$ ratios $(>3) .{ }^{228} \mathrm{Ra} /{ }^{226} \mathrm{Ra}$ ratios in those samples are discussed further in the section Discordant Radium Activity Ratios. The median ${ }^{228} \mathrm{Ra} /{ }^{226} \mathrm{Ra}$ ratio in the seven $\mathrm{SB}$ samples with ${ }^{228} \mathrm{Ra} /{ }^{226} \mathrm{Ra}$ ratios $<3$ is 1.4 , nearly identical to the median ratio in $\mathrm{LH}$ groundwater. ${ }^{228} \mathrm{Ra} /{ }^{226} \mathrm{Ra}$ ratios in the $\mathrm{LH}$ and $\mathrm{SB}$ samples are larger than the ratios in associated oil-field water samples (median ${ }^{228} \mathrm{Ra} /{ }^{226} \mathrm{Ra}$ ratio; $\mathrm{LH}=0.46, \mathrm{SB}=0.51$ ) (Figure $2 \mathrm{~B}$ ), possibly reflecting different water residence times, Ra mobilization mechanisms, and sediment chemistry between the oil reservoirs and aquifers. The oil-field water samples are mostly from organic-rich diatomite with ${ }^{228} \mathrm{Ra} /{ }^{226} \mathrm{Ra}$ ratios $<1 .{ }^{8}$
Median ${ }^{224} \mathrm{Ra} /{ }^{228} \mathrm{Ra}$ ratios in samples from $\mathrm{LH}(1.2)$ and $\mathrm{SB}$ (1.3) are near the ratio of 1 expected in the aquifer solids, assuming secular equilibrium between ${ }^{224} \mathrm{Ra}$ and ${ }^{228} \mathrm{Ra}$ (Figure $2 \mathrm{C}) .{ }^{18,33}{ }^{224} \mathrm{Ra} /{ }^{228} \mathrm{Ra}$ ratios in oil-field water from $\mathrm{LH}$ and $\mathrm{SB}$ are also mostly between 0.5 and 2 (median ${ }^{224} \mathrm{Ra} /{ }^{228} \mathrm{Ra}$ ratio; $\mathrm{LH}=$ $2.0, \mathrm{SB}=1.3$ ). A few groundwater samples have ${ }^{224} \mathrm{Ra} /{ }^{228} \mathrm{Ra}$ ratios $>2$, suggesting they were affected by relatively recent water-rock interactions through recoil processes. ${ }^{18,33,35}$

Geochemical Controls on Radium Activities in Groundwater. Radium activities in groundwater reflect the net effects of dissolution and precipitation of Ra-bearing minerals, radioactive decay of dissolved $\mathrm{Th}$, alpha-recoil release of $\mathrm{Ra}$ from the decay of $\mathrm{Th}$ in aquifer solids, decay of $\mathrm{Ra}$ in solution, and reversible $\mathrm{Ra}$ exchange processes with aquifer solids. ${ }^{35,38,39}$ Some of these processes, like Ra exchange and mineral precipitation, are affected by groundwater geochemistry (e.g., salinity, redox, $\mathrm{pH}) .^{18,19}$ Thus, regional variations in groundwater salinity, redox, and $\mathrm{pH}$ in the study area have implications for Ra occurrence in groundwater. TDS concentrations in groundwater increase substantially from the FV oil field on the east side of the SJV to the LH and SB oil fields on the west side of the valley [median TDS $(\mathrm{mg} / \mathrm{L}) ; \mathrm{FV}=206, \mathrm{LH}=$ $3520, \mathrm{SB}=4540$ ], whereas $\mathrm{pH}$ values decrease (median $\mathrm{pH}$; FV $=8.1, \mathrm{LH}=7.4, \mathrm{SB}=7.2$ ) (Figure $3 \mathrm{~A}$ ). In $\mathrm{FV}$, water types range from $\mathrm{Ca}-\mathrm{HCO}_{3}$ to $\mathrm{Na}-\mathrm{SO}_{4}$ (Figure $\mathrm{S} 2$ ). In $\mathrm{LH}$ and $\mathrm{SB}$, water types include mixed cation- $\mathrm{SO}_{4}$, mixed cation- $\mathrm{Cl}, \mathrm{Na}-\mathrm{SO}_{4}$, and $\mathrm{Na}-\mathrm{Cl}$. Groundwater in the FV oil field is more oxic, and contains less dissolved $\mathrm{Mn}$ and $\mathrm{Fe}$, than higher-TDS groundwater in the $\mathrm{LH}$ and $\mathrm{SB}$ oil fields $\left[\right.$ median $\mathrm{O}_{2}(\mathrm{mg} / \mathrm{L}) ; \mathrm{FV}=1.4$, $\mathrm{LH}=<0.1, \mathrm{SB}=0.2][$ median $\mathrm{Mn}+\mathrm{Fe}(\mathrm{mg} / \mathrm{L}) ; \mathrm{FV}=0.0034$, $\mathrm{LH}=0.85, \mathrm{SB}=0.36]$ (Figure 3B, Section S1).

Previous studies have shown that elevated Ra activities in groundwater are most commonly associated with elevated salinity, anoxic conditions indicated by elevated $\mathrm{Mn}$ and $\mathrm{Fe}$ and low $\mathrm{SO}_{4}$ concentrations, and/or low $\mathrm{pH} .^{18,19,32,39}$ Dissolved cations in saline groundwater can mobilize exchangeable $\mathrm{Ra}$ on clay minerals by outcompeting $\mathrm{Ra}^{2+}$ for exchange sites, with divalent cations generally being more effective than monovalent cations in the exchange process. ${ }^{32,39,40}$ Median concentrations (in $\mathrm{mg} / \mathrm{L}$ ) of $\mathrm{Ca}, \mathrm{Sr}$, and $\mathrm{Na}$ in $\mathrm{LH}(210,2.5,984)$ and SB $(445$, $9.8,640)$ groundwater are much higher than in FV (30, 0.35, 37 ), indicating that the substantial increase in groundwater salinity from east to west across the valley is accompanied by large increases in concentrations of divalent and monovalent cations. Strong positive Spearman correlations between total Ra 
A.

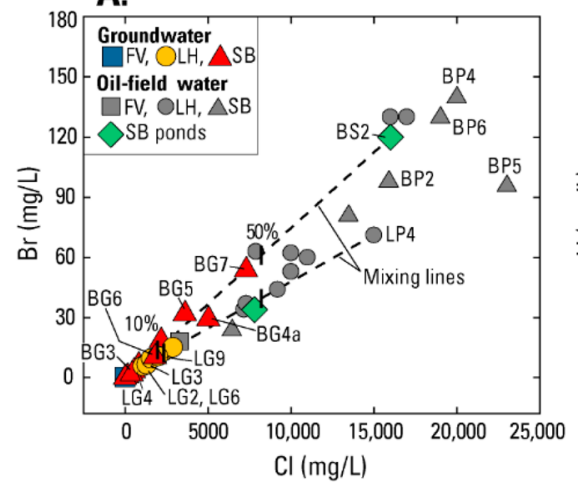

B.

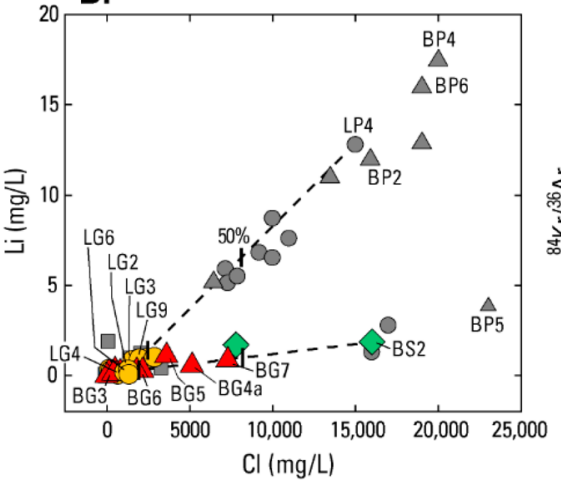

C.

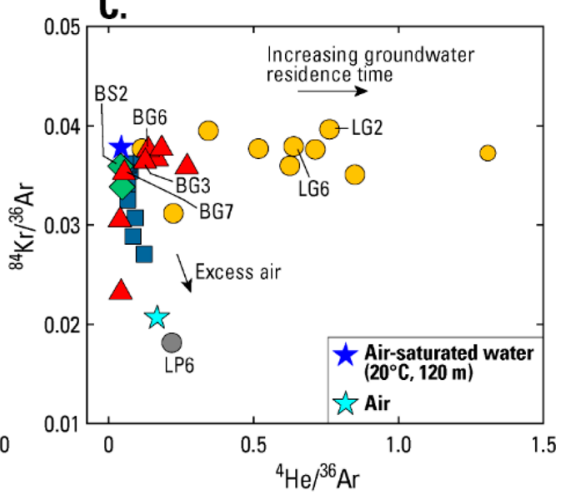

Figure 4. Concentrations of (A) bromide and (B) lithium in relation to chloride, (C) ${ }^{84} \mathrm{Kr} /{ }^{36} \mathrm{Ar}$ ratios in relation to ${ }^{4} \mathrm{He} /{ }^{36} \mathrm{Ar}$ ratios, in groundwater and oil-field water. Data for oil-field water from this study and refs 8, 31, and 37. In (A and B), vertical bars on the mixing lines represent mixtures containing $10 \%$ or $50 \%$ of the saline endmember.

and TDS $(p<0.001, \rho=0.90), \mathrm{Ca}(p<0.001, \rho=0.76), \mathrm{Sr}(p<$ $0.001, \rho=0.80)$, and $\mathrm{Na}(p<0.001, \rho=0.93)$ suggest salinity and water composition are important factors in mobilizing exchangeable Ra from the aquifer sediments.

$\mathrm{Mn}$ - and Fe-oxyhydroxide solids can be especially important sinks for dissolved $\mathrm{Ra}$ in some environments given their generally high exchange capacity; ${ }^{35,40-42}$ therefore, reductive dissolution of those phases under anoxic redox conditions could reduce the availability of exchange sites for dissolved $\mathrm{Ra}$ and release previously adsorbed $\mathrm{Ra}$ into solution. This conceptual model is supported by the strong positive correlations between total $\mathrm{Ra}$ and dissolved $\mathrm{Mn}(p<0.001, \rho=0.72)$ and $\mathrm{Fe}(P<$ $0.001, \rho=0.77)$. The dissolved $\mathrm{O}_{2}, \mathrm{Mn}$, and Fe data indicate that $\mathrm{Mn}$ and Fe reduction processes are more prevalent in SB and LH than FV (Figure 3B), which results in fewer Ra adsorption sites and thus higher dissolved-Ra activities in SB and LH. Ra adsorption on aquifer sediments is also $\mathrm{pH}$ dependent, with less adsorption occurring at lower $\mathrm{pH}$ due to the more positive surface charge on solid phases at lower $\mathrm{pH}^{39,40}$ The negative correlation between total $\mathrm{Ra}$ and $\mathrm{pH}(p<0.001, \rho=-0.67)$ is consistent with this model. Inverse correlations between $\mathrm{pH}$ and $\mathrm{Mn}(\mathrm{p}=0.005, \rho=-0.44)$ and $\mathrm{pH}$ and Fe $(p<0.001, \rho=$ $-0.65)$ could reflect $\mathrm{CO}_{2}$ production during microbial $\mathrm{Mn}$ and Fe reduction and thus decreased $\mathrm{pH}$ with intensification of those redox processes. ${ }^{43}$ Overall, the TDS, major-ion, $\mathrm{Mn}, \mathrm{Fe}$, and $\mathrm{pH}$ data indicate that geochemical conditions in $\mathrm{LH}$ and $\mathrm{SB}$ groundwater are more conducive to mobilizing exchangeable Ra than are the geochemical conditions in FV. Secondary barite coprecipitation, especially in the LH and SB oil fields, was evaluated as a Ra sink but appears to be less significant than processes mobilizing $\mathrm{Ra}$ based on persistently high $\mathrm{Ra}$ activities in LH and SB groundwater (Figure S3).

Gradients in salinity, redox conditions, and $\mathrm{pH}$ across the SJV are due in part to variations in recharge, aquifer lithology, and groundwater age across the valley. The presence of relatively dilute, oxic groundwater in FV is due to the Kern River, which is a major source of freshwater recharge to aquifers in the FV oil field (Figure 1). ${ }^{21}$ Aquifers on the east side of the SJV are also mostly composed of relatively coarse-grained sediments derived from granitic rocks in the Sierra Nevada that could enable extensive circulation of fresh recharge through the aquifer system. ${ }^{44-46}{ }^{3} \mathrm{H}$ and ${ }^{14} \mathrm{C}$-DIC data indicate the aquifers in $\mathrm{LH}$ and $\mathrm{SB}$ contain older groundwater than the aquifers in $\mathrm{FV}$ $\left[\right.$ median $\left.{ }^{3} \mathrm{H}(\mathrm{TU}) ; \mathrm{FV}=2.4 ; \mathrm{LH}<0.1, \mathrm{SB}=0.2\right]\left[\right.$ median ${ }^{14} \mathrm{C}$ $\mathrm{DIC}(\mathrm{pM}) ; \mathrm{FV}=83 ; \mathrm{LH}=1.3, \mathrm{SB}=3.6$ ] (Table S4), consistent with the lack of substantial sources of natural recharge in $\mathrm{LH}$ and SB and presence of the Corcoran Clay confining unit that could restrict groundwater flow. ${ }^{25,26,45}$ Aquifer lithology in LH and SB largely consist of reworked marine sediments derived from the Temblor Range to the west that contain calcite, dolomite, gypsum, and relatively organic-rich clay. ${ }^{25,44,45}$ Long groundwater residence times in sediments of that composition could produce anoxic conditions with relatively high TDS concentrations.

Some of the elevated TDS and anoxia in LH and SB groundwater could also be due to natural mixing of groundwater and oil-field water given the relatively small vertical separation between aquifers and underlying hydrocarbon reservoirs in those oil fields. ${ }^{23}$ Some of the sampled wells are also near unlined oil-field water disposal ponds, oil wells, and injection wells that had substantial water injection for EOR and disposal (Figure 1, Table S1). In those areas, oil and gas production activities could potentially cause oil-field water to mix with groundwater.

Groundwater Mixing with Oil-Field Water. Chloride, Br, $\mathrm{Li}, \mathrm{B}$, and stable water-isotope data are used in two-endmember mixing models to estimate fractions of oil-field water mixed with the seven Ra-rich groundwater samples. Noble-gas, ${ }^{3} \mathrm{H}$, and other data enable us to distinguish between groundwater mixed with oil-field water from unlined disposal ponds (anthropogenic source of oil-field water) and oil-field water from subsurface sources that could be related to natural mixing processes or oil and gas production. On the basis of these distinctions, the high$\mathrm{Ra}$ samples are grouped into 4 categories: (1) highly mixed, surface sources of oil-field water (BG4a, BG7), (2) slightly mixed, subsurface sources of oil-field water (LG3, LG9), (3) highly mixed, surface and subsurface sources of oil-field water (BG5), and (4) little or no mixing with oil-field water (LG2, LG6). A secondary data set for $\mathrm{NH}_{4}, \mathrm{DOC}$, VOCs, and $\delta^{13} \mathrm{C}$ DIC further supports the proposed binning of the high-Ra groundwater (Section S3).

Group 1 contains the two samples with the highest $\mathrm{Ra}$ activities in the SB area, BG4a and BG7 (Figure 1D). BG7 is $\sim 2.4 \mathrm{~km}$ downgradient from BS2, an unlined pond where oilfield water has been disposed of from the 1950s to present (2019). ${ }^{13}$ Wells BG7, BG6, and BG3 are aligned in a northeasterly direction downgradient from BS2, with BG7 located closest to BS2 and BG3 farthest from BS2 (Figure 1D). Chloride, $\mathrm{Br}, \mathrm{Li}$, and water-isotope data in those three wells show consistent patterns of increasing fractions of an end- 
member water source similar in composition to BS2 with decreasing distance from BS2 (Figures $3 \mathrm{C}$ and $4 \mathrm{~A}, \mathrm{~B}$ ). BS2 and BG3 are used as the saline-pond and dilute-groundwater endmembers, respectively, in the mixing calculations. The calculations suggest BG7 and BG6 contain roughly $45 \%$ and $10 \%$ disposal-pond water, respectively. Other potential oilfieldwater endmembers, such as BS3 and produced water similar in composition to previously sampled oil wells BP2 and BP4-BP6, ${ }^{8}$ do not show the same consistent mixing patterns as BS2 when considered in the context of all the tracers (Figures 1D, 3C, and 4A,B).

BG7 is an irrigation well in the Tulare Formation, indicating that water from BS2 either infiltrates directly into the Tulare Formation or enters by another pathway. BG7 has a long screened interval [ 74.7 to $165.2 \mathrm{~m}$ below land surface (bls)] that could extend a short distance above the Corcoran Clay based on geophysical-log data from an oil well (API 02903672) $0.35 \mathrm{~km}$ southeast of BG7 that identify the Corcoran Clay $\sim 76$ to $88 \mathrm{~m}$ bls. ${ }^{12}$ The gravel pack around the well screen in BG7 also extends upward to $\sim 15 \mathrm{~m}$ bls. The well screen and gravel pack could provide pathways for water above the Corcoran Clay to migrate below the clay. The water level in BG7 at the time of sampling in April 2017 (83.1 m bls) did not extend above the Corcoran Clay.

A large amount of water injection for EOR and disposal occurs in SB (Table S1); ${ }^{8}$ however, noble-gas data are not consistent with injected fluids as the source of high-TDS water in BG7. ${ }^{84} \mathrm{Kr} /{ }^{36} \mathrm{Ar}$ and ${ }^{4} \mathrm{He} /{ }^{36} \mathrm{Ar}$ ratios in a sample of oil-field injectate (LP6) suggest that injection water is greatly enriched in air, whereas the ratios in BG7 are like those in ASW and BS2 (Figure $4 C)$, consistent with BG7 having been in recent equilibrium with the atmosphere. Even though the noble-gas data indicate BG7 was recently exposed to the atmosphere, ${ }^{14} \mathrm{C}$-DIC in BG7 (5.1 $\mathrm{pM})$ is lower than in downgradient wells BG6 (6.9 pM) and BG3 (11.5 pM). Conceptually, this pattern is consistent with temporary storage of old oil-field water (lower ${ }^{14} \mathrm{C}$-DIC) at the land surface, allowing noble-gas equilibration with the atmosphere, followed by infiltration and mixing with younger ambient groundwater (higher ${ }^{14} \mathrm{C}$-DIC) downgradient from the pond. Isotopic exchange between atmospheric ${ }^{14} \mathrm{CO}_{2}$ and pond DIC could account for some of the ${ }^{14} \mathrm{C}-\mathrm{DIC}$ in BG7.

$\mathrm{BG} 4 \mathrm{a}$ has chemical characteristics like $\mathrm{BG} 7$, including elevated $\mathrm{Cl}, \mathrm{Br}, \mathrm{Li}$, and enriched $\delta^{2} \mathrm{H}-\mathrm{H}_{2} \mathrm{O}$ and $\delta^{18} \mathrm{O}-\mathrm{H}_{2} \mathrm{O}$ values (Figures $3 \mathrm{C}$ and $4 \mathrm{~A}, \mathrm{~B}$ ). BG4a is $\sim 3 \mathrm{~km}$ downgradient from an unlined oil-field water disposal pond that operated from the 1950 s to 2006 (Figure 1D). ${ }^{47}$ Chemical data suggest BG4a was affected by infiltration from that or another disposal pond with similar composition. Using the pond upgradient from BG4a and BG3 as the saline-pond and dilute-groundwater endmembers, respectively, mixing calculations based on $\mathrm{Cl}, \mathrm{B}$, and waterisotope data indicate that BG4a may contain $\sim 40 \%$ pond water (Figures S5A,B). ${ }^{47}$ Other similarities between BG4a and BG7 are that both contain ${ }^{3} \mathrm{H}$ ( 0.3 to $\left.0.5 \mathrm{TU}\right)$ (evidence of a recent connection to land surface) and both samples have $\mathrm{He} / \mathrm{Ne}$ ratios ( 0.264 to 0.321 ) only slightly higher than ASW $\left(0.242\right.$ at $20^{\circ} \mathrm{C}$, $120 \mathrm{~m}$ ), indicating relatively short groundwater residence times. Data from BG4a indicate pond seepage is present in the alluvial sediments, but chemical data from colocated well BG4b, screened in the Tulare Formation, indicate that pond seepage is not present in the Tulare Formation at that location.

Group 2 contains the two samples with the highest Ra activities in the LH area, LG3 and LG9 (Figure 2A). Mixing calculations based on the $\mathrm{Cl}, \mathrm{Br}, \mathrm{Li}$, and water-isotope data, and end-members represented by dilute Tulare groundwater (sample LG4) and an oil-field water sample unaffected by EOR or water disposal (LP4 in Figures 3 and 4$)^{8}$ suggest that LG3 and LG9 contain $\leq 10 \%$ oil-field water (Figures $3 \mathrm{C}$ and $4 A, B)$. Oil-field water in these samples appears to be from subsurface sources rather than pond infiltration. Neither sample contains ${ }^{3} \mathrm{H}$ and both samples contain high concentrations of $\mathrm{CH}_{4}$ (33 to $79 \mathrm{~mol} \%$ ) isotopically similar to $\mathrm{LH}$ oil-field gas (Figure S6A). Methane in oil-field water disposed of in ponds is expected to be low due to degassing ( $\left.\mathrm{BS} 2 \mathrm{CH}_{4}=1.71 \mathrm{~mol} \%\right)$. The mixing in LG3 and LG9 could be related to nearby oil and gas production activities and/or natural processes. Both wells have $>150$ oil-production and injection wells within $500 \mathrm{~m}$, and more than 9.5 million $\mathrm{m}^{3}$ of fluid were injected historically for EOR and water disposal within $500 \mathrm{~m}$ (Table S1). At the same time, the median depth to the top of the oil-well perforations in LH $(414 \mathrm{~m})^{23}$ is only $\sim 180$ to $215 \mathrm{~m}$ below the bottom of the perforations in LG3 and LG9, respectively (Table S1). Given this vertical separation between aquifers and reservoirs, it is conceivable that small amounts of natural mixing could occur over geologic time scales.

Group 3 consists of one sample from SB, BG5 (screened in the Tulare Formation), that is $\sim 0.5 \mathrm{~km}$ downgradient from an unlined disposal pond that operated from the 1950s until 2006 (Figure 1D). ${ }^{48}$ Using the pond upgradient from BG5 and nearby BG8 as the saline-pond and dilute-groundwater endmembers, respectively, mixing calculations based on $\mathrm{Cl}$ and $\mathrm{B}$ data indicate BG5 could contain roughly $40 \%$ saline water with a composition like that in the now inactive pond (Figure S5C). ${ }^{48}$ BG5 contains the highest ${ }^{3} \mathrm{H}$ concentration ( $0.6 \mathrm{TU}$ ) among the $\mathrm{LH}$ and SB groundwater samples, but it also contains elevated $\mathrm{CH}_{4}[24 \mathrm{~mol}$ $\%$; isotopically like SB oil-field gas (Figure S6A)]. The data indicate BG5 could contain oil-field fluids from both surface and subsurface sources (see section S3).

Group 4 consists of two samples from LH, LG2, and LG6 (Figure $\mathrm{1C}$ ). Chloride, $\mathrm{Br}, \mathrm{Li}$, and water-isotope data indicate those samples contain little or no oil-field water (Figures $3 \mathrm{C}$ and $4 \mathrm{~A}, \mathrm{~B})$. The absence of ${ }^{3} \mathrm{H}$ in the samples and their elevated ${ }^{4} \mathrm{He} /{ }^{36} \mathrm{Ar}$ ratios compared to ASW indicates long groundwater residence times without recent exposure to the atmosphere (Figure 4C).

Discordant Radium Activity Ratios. Of the high-Ra samples affected by mixing with oil-field water, only BG4a, BG7, and BG5 (groups 1 and 3) are clearly affected by oil and gas production activities distinct from natural processes. Data indicate that the groundwater represented by those samples is affected by infiltration from disposal ponds, yet discordance between Ra activity ratios in those samples $\left({ }^{228} \mathrm{Ra} /{ }^{226} \mathrm{Ra}\right.$; BG4a $=1.2$, BG5 $=7.2, \mathrm{BG} 7=3.1)$ and Belridge oil-field water samples that include the disposal ponds (median ${ }^{228} \mathrm{Ra} /{ }^{226} \mathrm{Ra}=0.51$ ) imply that $\mathrm{Ra}$ in the groundwater samples is not derived directly from mixing with oil-field water. This apparent inconsistency could be resolved if $\mathrm{Ra}$ in oil-field water disposed of in the ponds is retained in the near-pond environment and subsequently replaced by Ra mobilized from aquifer sediments affected by the saline, organic-rich pond water that infiltrates into the aquifers. Previous studies showed that $\mathrm{Ra}$ associated with surface releases of produced water is commonly entrained in sediments near the release site due to coprecipitation with barite and/or adsorption processes. ${ }^{6,14-16}$ Mixing calculations were done using PHREEQC to examine the potential for barite precipitation in the near-pond environment. ${ }^{49}$ Chemical data from BS2 (ref 31) represent the saline pond endmember, and 

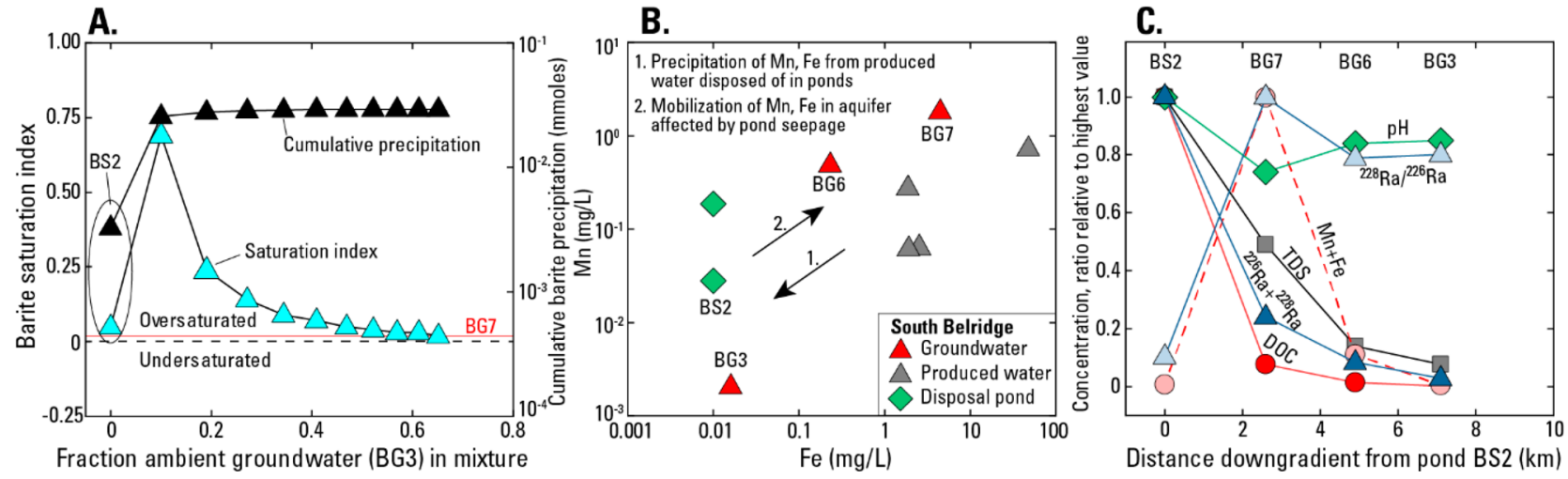

Figure 5. (A) Barite saturation index and cumulative barite precipitation, calculated using PHREEQC, in relation to the fraction of ambient groundwater in the mixture, (B) manganese concentrations in relation to iron concentrations in groundwater and oil-field water, and (C) relative concentrations and ratios in relation to distance downgradient from oil-field water disposal pond BS2. In (A), BG3 and BS2 represent the groundwater and oil-field water endmembers, respectively. In (B), iron concentrations in the pond samples plotted at one-half the reporting level of $0.02 \mathrm{mg} / \mathrm{L}$; data for oil-field water from refs 8 and 31.

data from BG3 represent the ambient groundwater endmember in the mixing calculations. For mixtures that result in barite oversaturation, barite saturation is achieved by allowing barite to precipitate in the model. BS2 is slightly oversaturated with respect to barite, requiring a small amount of barite precipitation in the pond (Figure 5A). Mixing pond water with $10 \%$ groundwater results in substantial barite oversaturation and precipitation because $\mathrm{BS} 2$ contains large concentrations of $\mathrm{Ba}$ $(4.8 \mathrm{mg} / \mathrm{L})$ and BG3 contains large concentrations of $\mathrm{SO}_{4}(996$ $\mathrm{mg} / \mathrm{L}$ ). Subsequent additions of groundwater cause increasingly smaller amounts of barite precipitation as barite saturation indexes approach equilibrium (Figure 5A). About $85 \%$ of the barite precipitation occurs in the pond and mixture containing $10 \%$ groundwater. The mixture reaches a barite saturation level comparable to BG7 when it contains $\sim 40 \%$ pond water (Figure $5 \mathrm{~A})$, near the mixing fraction indicated by the $\mathrm{Cl}, \mathrm{Br}$, and $\mathrm{Li}$ data (Figures 4A,B). The PHREEQC results indicate there is a high potential for $\mathrm{Ra}$ coprecipitation with barite in the near-pond environment.

Radium adsorption on $\mathrm{Mn}$ - and Fe-oxyhydroxides is also an important sink for $\mathrm{Ra}$ in water; ${ }^{17,19,32,39}$ therefore, $\mathrm{Mn}$ - and $\mathrm{Fe}$ oxyhdroxide precipitates formed in the near-pond environment could remove Ra originally present in oil-field water disposed of in the ponds. BS2 contains substantially less $\mathrm{Mn}$ and Fe than Belridge-produced water (Figure $5 \mathrm{~B}$ ), suggesting $\mathrm{Mn}$ and $\mathrm{Fe}$ in oil-field water disposed of in the pond is removed from solution in the near-pond environment, possibly by oxidation processes when oil-field water is exposed to the atmosphere. ${ }^{6}$

Assuming coprecipitation and adsorption processes in the near-pond environment remove Ra in oil-field water disposed of in the ponds, additional processes are needed to generate the $\mathrm{Ra}$ observed in BG7, BG4a, and BG5. A plot of relative ${ }^{226} \mathrm{Ra}+{ }^{228} \mathrm{Ra}$ activities in groundwater with distance from BS2 shows that an amount of Ra equivalent to about $25 \%$ of what is in the pond would need to be mobilized from aquifer sediments to account for the Ra in BG7 (Figure 5C). Infiltration of saline, organic-rich pond water into the aquifer could mobilize Ra from the aquifer sediments into salinized groundwater. Competing cations in the saline water could cause exchangeable Ra to desorb from aquifer solids. DOC in pond seepage could support microbial reduction of $\mathrm{Mn}$ - and Fe-oxyhydroxides in aquifer sediments, thereby reducing the ion-exchange capacity of aquifer sediments and mobilizing $\mathrm{Ra}$ adsorbed to the $\mathrm{Mn}$ and Fe solid phases. The spike in $\mathrm{Mn}+\mathrm{Fe}$ concentrations and decrease in DOC relative to TDS in BG7 indicate that substantial $\mathrm{Mn}$ and Fe mobilization occurred downgradient from BS2 (Figure 5C). The elevated Mn $+\mathrm{Fe}$ concentration in BG7 $(6300 \mu \mathrm{g} / \mathrm{L})$ is not likely related solely to natural processes, even though Tulare groundwater is typically anoxic. The $\mathrm{Mn}+\mathrm{Fe}$ and DOC concentrations in BG7 are $\sim 15$-to-100 and $\sim 26$-to-65 times higher, respectively, than the concentrations in SB Tulare samples not affected by pond seepage. Ra desorption could also occur if groundwater $\mathrm{pH}$ decreased due to $\mathrm{CO}_{2}$ production during microbial metabolism. $^{39,43}$ The spike in $\mathrm{Mn}+\mathrm{Fe}$ and dip in $\mathrm{pH}$ (to 6.4) in BG7 suggest such processes occur downgradient from BS2.

In sum, we propose that oil-field water from BS2 did not cause direct $\mathrm{Ra}$ contamination in BG7; rather, salination and development of reducing conditions in the downgradient groundwater by infiltration of oil-field water from BS2 triggered the mobilization of Ra from aquifer sediments with ${ }^{228} \mathrm{Ra} /{ }^{226} \mathrm{Ra}$ ratios like those in the sediments (Figure S7).

The ${ }^{228} \mathrm{Ra} /{ }^{226} \mathrm{Ra}$ ratio in $\mathrm{BG} 4 \mathrm{a}$ is in the range of ratios measured in aquifer sediments collected from the boreholes, consistent with the conceptual model of Ra mobilization from aquifer sediments by oil-field water leaked from the ponds (Figure $2 \mathrm{~B}$ ). The ${ }^{228} \mathrm{Ra} /{ }^{226} \mathrm{Ra}$ ratios in BG5 and BG7 are higher than measured ratios in the sediment. The higher ratios could simply reflect variability in ${ }^{228} \mathrm{Ra} /{ }^{226} \mathrm{Ra}$ ratios in aquifer sediments across the study area. This is supported by the observation that some other SB samples much less affected by mixing with oil-field water also had relatively high ${ }^{228} \mathrm{Ra} /{ }^{226} \mathrm{Ra}$ ratios (Figure $2 \mathrm{~B}$ ). It could also be possible that Ra desorption from sediment due to repeated intrusion of saline water and relatively rapid alpha-recoil regeneration of ${ }^{228} \mathrm{Ra}$ could contribute to the higher ${ }^{228} \mathrm{Ra} /{ }^{226} \mathrm{Ra}$ ratios. ${ }^{33,36}$

Implications. Chemical and isotopic data from this study show that saline, organic-rich oil-field water infiltrated through unlined disposal ponds into groundwater in multiple locations on the west side of the SJV. In three locations identified in this study, this has induced rock-water interactions that mobilize Ra from downgradient aquifer sediments to groundwater at levels that exceed the ${ }^{226} \mathrm{Ra}+{ }^{228} \mathrm{Ra}$ drinking-water MCL. These processes could also control $\mathrm{Ra}$ distribution in other areas with surface releases of produced water, rather than assuming high $\mathrm{Ra}$ is related to $\mathrm{Ra}$ adsorbed to sediment near the release site or that Ra activity in impacted groundwater depends 
only on conservative mixing relationships between the oil-field water and ambient groundwater. Induced-radium mobilization by oil-field and other saline water sources should be further studied in other cases, even if the end-member saline source has low Ra activity.

\section{ASSOCIATED CONTENT}

\section{S Supporting Information}

The Supporting Information is available free of charge on the ACS Publications website at DOI: 10.1021/acs.est.9b02395.

Study area description, analysis of radium in sediment, and additional analysis of groundwater mixing with oilfield water (PDF)

Geochemical data for groundwater and oil-field water samples (XLSX)

\section{AUTHOR INFORMATION}

\section{Corresponding Author}

*Phone: 303-236-6899; e mail: pmcmahon@usgs.gov.

\section{ORCID $\odot$}

Peter B. McMahon: 0000-0001-7452-2379

Avner Vengosh: 0000-0001-8928-0157

\section{Present Address}

${ }^{\perp}$ Woods Hole Oceanographic Institution, Woods Hole, Massachusetts 02543.

\section{Notes}

The authors declare no competing financial interest.

\section{ACKNOWLEDGMENTS}

This article was improved by the reviews of John Izbicki and anonymous reviewers for the journal. This work was funded by the California State Water Resources Control Board's Regional Groundwater Monitoring in Areas of Oil and Gas Production Program and the USGS Cooperative Water Program. A.V., A.J.K., and Z.W were supported by USDA-NIFA grant (\#201768007-26308). Any use of trade, firm, or product names is for description purposes only and does not imply endorsement by the U.S. Government.

\section{REFERENCES}

(1) Fuortes, L.; McNutt, L. A.; Lynch, C. Leukemia incidence and radioactivity in drinking water in 59 Iowa towns. Am. J. Public Health 1990, 80 (10), 1261-1262.

(2) Finkelstein, M. M.; Kreiger, N. Radium in drinking water and risk of bone cancer in Ontario youths: a second study and combined analysis. Occup. Environ. Med. 1996, 53 (5), 305-311.

(3) Canu, I. G.; Laurent, O.; Pires, N.; Laurier, D.; Dublineau, I. Health effects of naturally radioactive water ingestion: The need for enhanced studies. Environ. Health Perspect. 2011, 119 (12), 16761680.

(4) Drinking Water Contaminants - Standards and Regulations; U.S. Environmental Protection Agency, 2019. https://www.epa.gov/ dwstandardsregulations (accessed January 25, 2019).

(5) Rowan, E. L.; Engle, M. A.; Kirby, C. S.; Kraemer, T. F. Radium content of oil- and gas-field produced waters in the northern Appalachian Basin (USA)-Summary and discussion of data. Scientific Investigations Report 2011-5135; U.S. Geological Survey: VA, 2011.

(6) Lauer, N. E.; Harkness, J. S.; Vengosh, A. Brine spills associated with unconventional oil development in North Dakota. Environ. Sci. Technol. 2016, 50 (10), 5389-5397.

(7) A Study of NORM Associated with Oil and Gas Production Operations in California; California Department of Conservation: CA,
1996. https://www.conservation.ca.gov/dog/pubs stats/Pages/ technical_reports.aspx (accessed December 13, 2018).

(8) McMahon, P. B.; Kulongoski, J. T.; Vengosh, A.; Cozzarelli, I. M.; Landon, M. K.; Kharaka, Y. K.; Gillespie, J. M.; Davis, T. A. Regional patterns in the geochemistry of oil-field water, southern San Joaquin Valley, California, USA. Appl. Geochem. 2018, 98 (1), 127-140.

(9) Kraemer, T. F.; Reid, D. F. The occurrence and behavior of radium in saline formation water of the U.S. Gulf Coast region. Chem. Geol. 1984, 46 (2), 153-174.

(10) Langmuir, D.; Riese, A. C. The thermodynamic properties of radium. Geochim. Cosmochim. Acta 1985, 49 (7), 1593-1601.

(11) Herczeg, A. L.; Simpson, H. J.; Anderson, R. F.; Trier, R. M.; Mathieu, G. G.; Deck, B. L. Uranium and radium mobility in groundwaters and brines within the Delaware Basin, southeastern New Mexico, U.S.A. Chem. Geol. 1988, 72 (2), 181-196.

(12) Oil \& Gas Online Data. California Department of Conservation, Division of Oil, Gas, and Geothermal Resources: CA, 2018 http:// www.conservation.ca.gov/dog/Online_Data/Pages/Index.aspx (accessed January 28, 2019).

(13) Belgian Anticline Oil Field, McKittrick 1-1 Facility (L10004955136). California State Water Resources Control Board:CA, 2018. https://geotracker.waterboards.ca.gov/profile report. asp?global_id=L10004955136 (accessed December 13, 2018).

(14) Zielinski, R. A.; Budahn, J. R. Mode of occurrence and environmental mobility of oil-field radioactive material at US Geological Survey research site B, Osage-Skiatook Project, northeastern Oklahoma. Appl. Geochem. 2007, 22 (10), 2125-2137.

(15) Akob, D. M.; Mumford, A. C.; Orem, W.; Engle, M. A.; Klinges, J. G.; Kent, D. B.; Cozzarelli, I. M. Wastewater disposal from unconventional oil and gas development degrades stream quality at a West Virginia injection facility. Environ. Sci. Technol. 2016, 50 (11), $5517-5525$

(16) Lauer, N. E.; Warner, N. R.; Vengosh, A. Sources of radium accumulation in stream sediments near disposal sites in Pennsylvania: Implications for disposal of conventional oil and gas wastewater. Environ. Sci. Technol. 2018, 52 (3), 955-962.

(17) Landa, E. R.; Reid, D. F. Sorption of radium-226 from oilproduction brine by sediments and soils. Environ. Geol. 1983, 5 (1), 18.

(18) Vengosh, A.; Hirschfeld, D.; Vinson, D.; Dwyer, G.; Raanan, H.; Rimawi, O.; Al-Zoubi, A.; Akkawi, E.; Marie, A.; Haquin, G.; Zaarur, S.; Ganor, J. High naturally occurring radioactivity in fossil groundwater from the Middle East. Environ. Sci. Technol. 2009, 43 (6), 1769-1775.

(19) Vinson, D. S.; Tagma, T.; Bouchaou, L.; Dwyer, G. S.; Warner, N. R.; Vengosh, A. Occurrence and mobilization of radium in fresh to saline coastal groundwater inferred from geochemical and isotopic tracers. Appl. Geochem. 2013, 38 (1), 161-175.

(20) Scheirer, A. H.; Magoon, L. B. Age, distribution, and stratigraphic relationship of rock units in the San Joaquin Basin Province, California. Professional Paper 1713, Ch. 5; U.S. Geological Survey:VA, 2007.

(21) Wright, M. T.; McMahon, P. B.; Landon, M. K.; Kulongoski, J. T. Groundwater quality of a public supply aquifer in proximity to oil development, Fruitvale oil field, Bakersfield, California. Appl. Geochem. 2019, 106 (1), 82-95.

(22) Olson, H. C.; Miller, G. E.; Bartow, J. A. Stratigraphy, paleoenvironment and depositional setting of Tertiary sediments, southeastern San Joaquin Basin. In Southeast San Joaquin Valley Field Trip, Kern County, California; Bell, P., Ed.; Field Trip Guidebook 56, Part II: Structure and Stratigraphy, Am. Assoc. Petrol. Geol. Pacific Section, Bakersfield, CA, 1986; pp 18-55.

(23) Davis, T. A.; Landon, M. K.; Bennett, G. L. Prioritization of oil and gas fields for regional groundwater monitoring based on a preliminary assessment of petroleum resource development and proximity to California's groundwater resources; Scientific Investigations Report 2018-5065; U.S. Geological Survey: VA, 2018.

(24) Stephens, M. J.; Shimabukuro, D. H.; Gillespie, J. M.; Chang, W. Groundwater salinity mapping using geophysical log analysis within the Fruitvale and Rosedale Ranch oil fields, Kern County, California, USA. Hydrogeol. J. 2019, 27 (2), 731-746. 
(25) Kiser, S. C. Lithofacies of the Pleistocene to Recent sediments in western Kern County, California. San Joaquin Geol. Soc. 1988, 7, 14-21. (26) Faunt, C. C. Groundwater availability of the Central Valley aquifer; Professional Paper 1766; U.S. Geological Survey: VA, 2009.

(27) OriginLab Corporation. OriginPro 2018 Software, 2018. http:// www. OriginLab.com (accessed January 9, 2018).

(28) Dillon, D. B.; Davis, T. A.; Landon, M. K.; Land, M. T.; Wright, M. T.; Kulongoski, J. T. Data from exploratory sampling of groundwater in selected oil and gas areas of coastal Los Angeles County and Kern and Kings Counties in southern San Joaquin Valley, 2014-15: California oil, gas, and groundwater project; Open-File Report 2016 - 1181; U.S. Geological Survey:VA, 2016.

(29) McCarlson, A.; Wright, M. T.; Teunis, J. A.; Davis, T. A.; Johnson, J.; Qi, S. L. Water chemistry data for samples collected at groundwater sites near the Fruitvale oil field, September 2016-February 2017 Kern County, California; Data Release; U.S. Geological Survey: VA, 2018, DOI: 10.5066/F7ZW1K7T.

(30) Davis, T. A.; Teunis, J. A.; McCarlson, A. J.; Seitz, N. O.; Johnson, J. C. Water chemistry data for samples collected at groundwater and surface-water sites near the Lost Hills and Belridge oil fields, November 2016-September 2017, Kern County, California, Data Release; U.S. Geological Survey: VA, 2018, DOI: 10.5066/F7NS0T5M.

(31) Gannon, R. S.; Saraceno, J. F.; Kulongoski, J. T.; Teunis, J. A.; Barry, P. H.; Tyne, R. L.; Kraus, T. E. C.; Hansen, A. M.; Qi, S. L. Produced water chemistry data for the Lost Hills, Fruitvale, and North and South Belridge study areas, Southern San Joaquin Valley, California, Data Release; U.S. Geological Survey:VA, 2018 DOI: 10.5066/F7X929H9.

(32) Sturchio, N. C.; Banner, J. L.; Binz, C. M.; Heraty, L. B.; Musgrove, M. Radium geochemistry of groundwaters in Paleozoic carbonate aquifers, midcontinent, USA. Appl. Geochem. 2001, 16 (1), 109-122.

(33) Hancock, G. J.; Murray, A. S. Source and distribution of dissolved radium in the Bega River estuary, southeastern Australia. Earth Planet. Sci. Lett. 1996, 138 (1-4), 145-155.

(34) The Environmental Behavior of Radium: Revised ed.; Technical Report Series No. 476; International Atomic Energy Agency: Vienna, 2014.

(35) Vinson, D. S. Radium isotope geochemistry in groundwater systems: The role of environmental factors. Ph.D. Dissertation, Duke University, Durham, NC, 2011.

(36) Lamontagne, S.; Le Gal La Salle, C.; Hancock, G. J.; Webster, I. T.; Simmons, C. T.; Love, A. J.; James-Smith, J.; Smith, A. J.; Kämpf, J.; Fallowfield, H. J. Radium and radon radioisotopes in regional groundwater, intertidal groundwater, and seawater in the Adelaide Coastal Waters Study area: Implications for the evaluation of submarine groundwater discharge. Mar. Chem. 2008, 109 (3-4), 318-336.

(37) U.S. Geological SurveyNational Water Information SystemWeb Interface, 2018, DOI: 10.5066/F7P55KJN (accessed November $8,2018)$.

(38) Krishnaswami, S.; Graustein, W. C.; Turekian, K. K. Radium, thorium, and radioactive lead isotopes in groundwaters: Application to the in situ determination of adsorption-desorption rate constants and retardation factors. Water Resour. Res. 1982, 18 (6), 1633-1675.

(39) Szabo, Z.; DePaul, V. T.; Fischer, J. M.; Kraemer, T. F.; Jacobsen, E. Occurrence and geochemistry of radium in water from principal drinking-water aquifer systems in the United States. Appl. Geochem. 2012, 27 (3), 729-752.

(40) Chen, M. A.; Kocar, B. D. Radium sorption to iron (hydr)oxides, pyrite, and montmorillonite: Implications for mobility. Environ. Sci. Technol. 2018, 52 (7), 4023-4030.

(41) Moore, W. S.; Reid, D. F. Extraction of radium from natural waters using manganese-impregnated acrylic fibers. J. Geophys. Res. 1973, 78 (36), 8880-8886.

(42) Ames, L. L.; McGarrah, J. E.; Walker, B. A.; Salter, P. F. Uranium and radium sorption on amorphous ferric oxyhydroxide. Chem. Geol. 1983, 40 (1-2), 135-148.

(43) Chapelle, F. H.; Lovley, D. R. Rates of microbial metabolism in deep coastal plain aquifers. Appl. Environ. Microbiol. 1990, 56 (6), 1865-1874.
(44) Berryman, W. M. Lithologic characteristics of Pliocene rocks cored at Elk Hills, Kern County, California; Bulletin 1332-D; U.S. Geological Survey:VA, 1973.

(45) Page, R. W. Geology of the Tulare Formation and other continental deposits, Kettleman City area, San Joaquin Valley, California, with a section on groundwater management considerations and use of texture maps; Water-Resources Investigations Report 83-4000; U.S. Geological Survey:VA, 1983.

(46) Page, R. W. Geology of the fresh groundwater basin of the Central Valley, California, with texture maps and sections; Professional Paper 1401-C; U.S. Geological Survey:VA, 1986.

(47) South Belridge Oil Field, South Wastewater Disposal Facility (SL0602990565); California State Water Resources Control Board: CA, 2019, https://geotracker.waterboards.ca.gov/profile_report. asp?global_id=SL0602990565 (accessed January 25, 2019).

(48) South Belridge Oil Field, Hill Lease (SL0602935481); California State Water Resources Control Board: CA, 2018, https://geotracker. waterboards.ca.gov/profile_report?global_id= SL0602935481\&mytab=esidata\#esidata (accessed December 13 , 2018).

(49) Parkhurst, D. L.; Appelo, C. A. J. Description of input and examples for PHREEQC version 3-A computer program for speciation, batchreaction, one-dimensional transport, and inverse geochemical calculations; Techniques and Methods, Book 6, chapter A43; U.S. Geological Survey: Richmond, VA, 2013.

(50) Rozanski, K.; Araguás-Araguás, L.; Gonfiantini, R. Isotopic patterns in modern global precipitation. In Climate Change in Continental Isotopic Records; Swart, P. K., Lohmann, K. C., McKenzie, J., Savin, S., Eds.; V. 78 American Geophysical Union Geophysical Monograph 78; American Geophysical Union: Washington, D.C., 1993; pp 1-36.

(51) Shelton, L.; Pimentel, I.; Fram, M. S.; Belitz, K. Ground-water quality data in the Kern County subbasin study unit, 2006: Results from the California GAMA Program; Data Series 337; U.S. Geological Survey: Richmond, VA, 2008. 